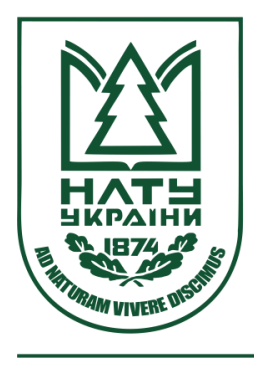

Науковий вісник НЛтУ України Scientific Bulletin of UNFU

https://nv.nltu.edu.ua

https://doi.org/10.36930/40310410

$@ \bowtie$ Correspondence author

Article received 13.08.2021 p.

Article accepted 09.09.2021 p.

V. F. Pylypchuk blossom@i.ua

UDC 904:72:712.253:58:069.029(477-25)

В. Ф. Пилипчук, Р. В. Бойко

Національний ботанічний сад ім. М. М. Гришка, НАН Украӥни, м. Київ, Украӥна

\title{
РОЗРОБЛЕННЯ ЗАХОДІВ ІЗ РЕПРЕЗЕНТАЦІЇ ІСТОРИКО-КУЛЬТУРНОЇ ПАМ'ЯТКИ "ЗВІРИНЕЦЬКЕ УКРІПЛЕННЯ КИЇВСЬКОЇ ФОРТЕЦІ 1810 Р." НА ТЕРИТОРІЇ НАЦІОНАЛЬНОГО БОТАНІЧНОГО САДУ ІМЕНІ М. М. ГРИШКА НАН УКРАЇНИ
}

\begin{abstract}
Дослідження історичного минулого території, популяризація та презентація пам'яток природної та культурної спадщини $\epsilon$ одним із сучасних перспективних напрямів роботи Національного ботанічного саду ім. М. М. Гришка НАН України. Встановлено, що пам'ятка містобудування національного значення "Звіринецьке укріплення Київської фортеці 1810 р.", яка розмішена на території ботанічного саду, на сьогодні залишається одним 3 маловідомих історико-фортифікаційних об'єктів держави. З'ясовано, що заходи із репрезентації історико-культурних пам'яток на територіях об'єктів природно-заповідного фонду України (ПЗФУ) мають свої особливості та розробляються з урахуванням законодавчих вимог режиму охорони і збереження природного середовища таких територій. Дослідження здійснено у 2018-2021 рр. на території ботанічного саду 3 використанням описового та порівняльного методів. Для визначення збережених елементів використано дані Паспорта пам'ятки "Звіринецьке укріплення Київської фортеці 1810 р.". За результатами досліджень за методикою О. В. Коваленко (2020) розроблено новий екскурсійний маршрут протяжністю близько 3 км з траєкторією, що повторює контури унікального укріплення і репрезентує пам'ятку національного значення. Графічну складову маршруту виконано 3 використанням прикладної програми Геоінформаційної системи (ГIC) "Quantum GIS (QGIS)", графічних програм "Adobe Photoshop CS5" та "Adobe Illustrator CC 19.1.0". Особливістю цього маршруту є поєднання історичної інформації про пам'ятку з інформацією про унікальні ландшафти сучасних колекційно-експозиційних ділянок ботанічного саду з репрезентаційними рослинами, які розташовані в межах укріплення. Маршрут прокладено через колекційно-експозиційні ділянки "Сад ароматів", "Гірський сад", "Трояндовий струмок", "Голонасінні", "Березовий гай", де збережено більшість елементів фортифікаційної споруди. Виявлено деякі елементи укріплення, які не було занесено до Паспорта пам'ятки - Контрміні галереї та Гласис перед Південним люнетом. Рекомендовано використання на території НБС та подібних територіях ПЗФУ інформаційних стендів, зокрема оснащених QR-кодами, які сприятимуть популяризації і збереженню об'єктів історико-культурної спадщини та впровадженню інновацій, цифрових технологій та діджиталізації у сфері охорони природи та заповідної справи.
\end{abstract}

Ключові слова: культурна спадщина; еколого-історичний маршрут; колекційно-експозиційні ділянки НБС; територія природно-заповідного фонду; фортифікаційні елементи укріплення.

\section{Вступ / Introduction}

Збереження природної та історико-культурної спадщини, як основи самоідентифікації нації - одне із головних питань державної політики сьогодення. Важливу роль у вирішенні цього питання відіграють ботанічні сади, які мають тісний історичний зв'язок 3 місцевістю, де вони розташовані та активно виступають як посередники зв'язку між природною та історико-культурною спадщиною держави [5]. Національний ботанічний сад ім. М. М. Гришка НАН України (НБС) $є$ унікальним науково-дослідницьким і культурно-просвітницьким закладом України, на території якого гармонійно поєднані цінний природний ландшафт, колекції інтродукованих живих рослин, науково-дослідницькі ділянки, а також пам'ятки та об'єкти культурної спадщини національного та місцевого значення: містобудування, архітектури, історії, археології, ботанічні пам'ятки природи.

Проте історико-культурний потенціал НБС на сьогодні використовують не в повному обсязі. Тому одним із стратегічних напрямів еколого-просвітницької роботи установи $є$ обгрунтування та проєктування нових екскурсійних маршрутів із залученням наявних на території пам'яток історико-культурної спадщини та пам'яток природи. Цікавим об'єктом історико-культурної спадщини на території ботанічного саду є пам'ятка містобудування національного значення "Звіринецьке укріплення Київської фортеці 1810 р.". Пам'ятка має значну історико-культурну цінність, репрезентує шедевр творчого генія військових фортифікаторів початку XIX ст., проте на сьогодні залишається однією з маловідомих у держа-

Інформація про авторів:

Пилипчук Валентина Федорівна, канд. біол. наук, ст. наук. співробітник, відділ ландшафтного будування. Email: blossom@i.uа; https://orcid.org/0000-0003-4756-8077

Бойко Рита Василівна, пров. інженер, відділ ландшафтного будування. Email: Rita-Boiko@ukr.net; https://orcid.org/0000-0003-3187-8820

Цитування за ДСТУ: Пилипчук В. Ф., Бойко Р. В. Розроблення заходів із репрезентації історико-культурної пам'ятки "Звіринецьке укріплення київської фортеці 1810 р." на території національного ботанічного саду імені м. М. Гришка НАН України. Науковий вісник НлтУ України. 2021, т. 31, № 4. С. 65-70.

Citation APA: Pylypchuk, V. F., \& Boiko, R. V. (2021). Mysteries of the Zvirynets Fortifications Monument on the territory of the M. M. Gryshko National Botanical Garden of the National Academy of Sciences of Ukraine. Scientific Bulletin of UNFU, 31(4), 65-70. https://doi.org/10.36930/40310410 
ві і вірогідність ії втрати для майбутніх поколінь $є$ дуже високою. Репрезентацію та охорону пам'ятки ускладнює і той факт, що іiі межі не винесені в натуру, тобто не позначені на території ботанічного саду.

Національний ботанічний сад входить до природнозаповідного фонду України (ПЗФУ) з територією комплексної охорони і належить до земель природного та історико-культурного призначення, які охороняються як національне надбання держави. Тому впровадження заходів із популяризації та репрезентації історико-культурних пам'яток мають свої особливості. Розроблення еколого-просвітницького екскурсійного маршруту як активного заходу популяризації та репрезентації історичної пам'ятки 3 дотриманням вимог режиму охорони і збереження природного середовища території іï розташування, $є$ актуальним.

Об'єкт дослідження - архівні та наукові матеріали історії Звіринецького укріплення, збережені елементи пам'ятки та рослини колекційних ділянок ботанічного саду, інформаційно-презентаційні стенди.

Предмет дослідження - розроблення історико-екологічного екскурсійного маршруту "Таємниці Звіринецького Укріплення" на території НБС".

Мета роботи - теоретично обгрунтувати та запропонувати для впровадження активний захід із репрезентації історико-культурної пам'ятки "Звіринецьке укріплення Київської фортеці 1810 р." для популяризації і репрезентації історико-культурної пам'ятки та сучасних колекційно-експозиційних ділянок ботанічного саду, що розташовані в межах укріплення.

Для досягнення зазначеної мети визначено такі оcновні завдання дослідження: використовуючи наукові матеріали з історії Звіринецького укріплення обстежити елементи пам'ятки в натурі за участю фахівців-істориків Київської фортеці та виявити найбільш атрактивні збережені елементи для їхньої репрезентації; врахувати особливості розташування елементів пам'ятки на території ботанічного саду та їх зв'язок із рослинами колекційно-експозиційних ділянок; розробити траєкторію маршруту та інформаційно-презентаційні стенди, зокрема з використанням сучасних цифрових технологій.

Наукова новизна отриманих результатів дослідження - вперше розроблено активний захід з репрезентації пам'ятки історико-культурної спадщини на території об'єкта природно-заповідного фонду, шляхом комплексного впровадження міждисциплінарних знань з історії, культурології, ботаніки, екології, природоохоронної справи тощо.

Практична значущість результатів дослідження розроблений еколого-історичний екскурсійний маршрут дасть змогу широкому загалу людей отримати інформацію та відвідати маловідому пам'ятку історикокультурної спадщини, розташованої на території ботанічного саду; отримати додаткову інформацію про колекційно-експозиційні ділянки 3 репрезентативними рослинами, що розташовані за маршрутом. Досвід розробки може бути використаним для популяризації та репрезентації інших пам'яток історико-культурної спадщини на території НБС та подібних територіях ПЗФУ, дасть змогу збільшити зацікавлену аудиторію відвідувачів завдяки історикам, культурологам, любителям фортифікації та іншим верствам населення.

Аналіз останніх досліджень та публікацій. Питанню організації раціонального природокористування на територіях різних категорій природно-заповідного фонду України з веденням широкої просвіти екологічного та природоохоронного напрямів фахівці приділяють значну увагу. У роботах Черевченко Т. М., Трофименко Н. М. (2011); Заіменко Н. В., Мележик О. О. (2015); Андрієнко Т. Л., Онищенко В. А., Клєстов М. Л. та ін. (2001); Боярин М. В., Волошин В. У., Цьось О. О. (2020); Онищенко В. А., 2000; Подольхова М. О. (2018); Шевцова Л. В., Шевцова Н. Л., Глуховського П. В. (2018) відведено належне місце аналізу теоретичних та практичних питань забезпечення режиму охорони та порядку використання природоохоронних територій, методам та практиці освітньо-виховної та інших видів діяльності в межах ПЗФ України [2, 3, 4, 13, 19, 23].

Про важливість та потреба популяризації культурної спадщини неодноразово наголошують у конвенції "Про охорону всесвітньої культурної і природної спадщини" 1972 року, яку Україна ратифікувала у 1988 р. [10].

Екскурсійні маршрути з репрезентації пам'яток історико-культурної спадщини є найперспективнішими активними заходами популяризації та збереження культурних скарбів нації. У роботах М. В. Гриньової, А. А. Арканової, Л. Альтгайм, О. Бордун та ін. особливого значення надають розробкам авторських екскурсійних маршрутів на територіях ПЗФУ $[1,7]$.

Питання популяризації об'єктів історико-культурної спадщини на територіях ботанічних садів порушували дослідники цієї категорії установ [8, 9, 18]. Тому обгрунтування та проектування нових екскурсійних маршрутів із залученням наявних історико-культурних пам'яток та колекційно-експозиційних ділянок з використанням програми ГІС ботанічного саду є важливим напрямом еколого-просвітницької роботи НБС.

Матеріал і методи дослідження. Роботи з розроблення маршруту та дослідження виконували у 20182021 pp. на території НБС, який розташовано у Печерському районі міста Києва. Під час дослідження використовували методи бібліографічних, архівних, картографічних, іконографічних досліджень. Для визначення збережених елементів, що вказані у Паспорті пам'ятки Звіринецьке укріплення Київської фортеці 1810 р., використовували такі методи: спостереження, описовий та порівняльний [14].

Під час розроблення екскурсійного маршруту використано методику О. В. Коваленко [11]. Графічну складову маршруту, а також визначення загальної площі укріплення та збережених іiї елементів здійснювали з використанням прикладної програми Геоінформаційної системи (ГIC) "Quantum GIS (QGIS)", графічних програм "Adobe Photoshop CS5" та "Adobe Illustrator CC 19.1.0"; Протяжність маршруту та площу укріплення визначали за допомогою ГIC QuantumGIS.

Установлені за маршрутом знаки розроблено згідно 3 "Положенням про єдині державні знаки та аншлаги на територіях та об'єктах природно-заповідного фонду України", затвердженого Наказом Міністерства охорони навколишнього природного середовища України від 29 березня 1994 р., № 30 [17].

\section{Результати дослідження та їх обговорення / Research results and their discussion}

Національний ботанічний сад розташований у південно-західній (правобережній) частині Києва на величезному плато Звіринецької гори, що входить до складу 
Київської височини [21]. Характерні форми рельєфу Київського правобережжя - гори-останці, зокрема Старокиївська, Печерська, Щекавиця, Хоревиця, Звіринецька, Чорна, Лиса, Батиєва, а також яри: Бабин, Смородинський, Кметів, Протасів та інші. Перевищення відносних висот на правобережжі сягає 100-105 м [6].

Своєрідний рельєф Звіринецьких пагорбів було використано під час зведення Звіринецького земляного укріплення бастіонного типу у 1810-1812 рр. за проєктом інженера Карла Оппермана. Основним стратегічним завданням будівництва цієї фортикаційної споруди стала потреба зміцнення та охорони Києво-Печерської фортеці на сусідній Старокиївській горі, а також контроль переправи у Наводницькому яру, який розділяв ці гори-останці. До зведення Звіринецького укріплення південно-східна частина Києво-Печерської фортеці була не захищена [22].

Фортечний фронт Звіринецького укріплення 1810 p. складався із шести полігонів, висунутого до північного сходу гонверка, чотирьох бастіонів (південні - Видубецький і Великий, північні - Повний і Печерський), доповнених ззовні редантами, люнетами і флешами. Всередині процесу укріплення містилися тимчасові казарми й землянки для гарнізону, артилерійські і продуктові склади $[20,24]$.

У 1813 р., після того як з'ясувалося, що наполеонівська армія не дійде до Києва, роботи у фортеці припинилися. У 1850 р. після зведення "з'єднаних з цитаделлю укріплень Нової Київської фортеці" було прийнято рішення про вилучення Звіринецького укріплення 3 оборонної системи міста. Укріплення мало бути повністю розібрано, однак через брак коштів та людських ресурсів реалізувати цей намір не вдалось [22].

Першу спробу пристосувати територію укріплення під потреби міста зробив гетьман Павло Скоропадський, який у 1918 р. запланував розмістити на об'єднаній території Печерська та Звіринця урядові установи нового адміністративного центру Києва, зокрема ботанічний сад та будівлі щойно створеної Академії наук.

Довгий час вважали історичним фактом, що через вибух військових складів у Звіринецькому укріпленні в 1918 р., фортифікаційна споруда була повністю зруйнована. Як наслідок - відсутність достовірної інформації про роль укріплення в історичних подіях та розвитку місцевості Звіринець упродовж майже столітнього періоду [22]. Сучасні дослідження А. В. В'ялця та О. Г. Кузяк з використанням архівних фотодокументальних матеріалів, спростували це хибне твердження про причетність Звіринецького укріплення до трагічного за своїми наслідками вибуху. I тільки під час будівництва Центрального республіканського ботанічного саду Академії наук УРСР (сучасного Національного ботанічного саду імені М. М. Гришка НАН України) в період 1944-1964 pp. фортифікаційну споруду було частково розібрано.

У 2012 р. Звіринецьке укріплення Київської фортеці 1810 р. набуло статусу пам'ятки містобудування національного значення, що має велику історико-культурну цінність, відповідає критерію автентичності (певною мірою має збережене своє розпланування, історичні нашарування, композиційні компоненти та ін.), безпосередньо пов'язано з історичними подіями, життям та діяльністю видатних людей [16].

Унаслідок досліджень сучасної центральної та північно-східної частин території НБС встановлено, що укріплення згідно з планом зазначеним у Паспорті, займає площу 20,1 га, збережені фортифікаційні елементи пам'ятки займають площу 2,09 га, контури фортеці мають форму неправильної пентаграми - "зірки".

Основні елементи історичного планування укріплення, зокрема Видубицький бастіон, Печерський бастіон, Повний бастіон, гонверк, північний та південний люнети, а також равелін були використані як атрактивні елементи під час розроблення маршруту.

Разом із фахівцями Національного історико-архітектурного музею Київська фортеця на території сучасних колекційно-експозиційних ділянок "Сад Ароматів" та "Декоративні представники родини Cornaceae" було виявлено нові елементи пам'ятки, що залишилися поза увагою Паспорта пам'ятки, а саме Контрміні галереї та Гласис перед Південним люнетом, які також стали складовою частиною нового маршруту "Таємниці Звіринецького укріплення".

Особливістю розробленого маршруту є поєднання історичної інформації пам'ятки з інформацією про репрезентативну ботанічну складову сучасних колекційноекспозиційних ділянок ботанічного саду, що розташована в межах укріплення (табл. 1). Маршрут прокладено через ділянки "Сад ароматів", "Гірський сад", "Трояндовий струмок", "Голонасінні", "Березовий гай", де збережено більшість елементів укріплення.

За маршрутом розроблено дев'ять локацій найкращого візуального сприйняття основних збережених елементів укріплення, на яких буде встановлено спеціальні інформаційно-презентаційні стенди, що містять графічну та текстову складові: зображення укріплення на карті ботанічного саду; позначення меж та назв колекційно-експозиційних ділянок; напрямок маршруту; текстовий інформаційний блок 3 можливістю доступу до розширеної інформації через посилання QR-кодів на відповідні Веб-сайти, шляхом використання платформи ZERUM.

Екскурсійний маршрут розпочинається з огляду експозиції "Сад ароматів". Саме на цій ділянці в минулому розміщувалися Контрміні галереї та Гласис перед Південним люнетом Звіринецького укріплення. На ділянці вирощують близько 80 таксонів рослин, що належать переважно до родин Asteraceae Bercht. \& J. Presl; Lamiaceae Martinov; Verbenaceae J. St.-Hil., nom. cons.; Oleaceae Hoffmanns. \& Link, nom. cons.; Rosaceae Juss.; Fabaceae Lindl., та інші (рис. 1).

Локація Равелін Звіринецького укріплення трансформована у сучасну колекційно-експозиційну ділянку "Гірський сад" - штучний гірський ландшафт, який сприймається цілком природно. На ділянці висаджено 145 таксонів рослин, що належать до родин Cupressaceae Gray, Taxaceae Cray, Rosaceae Juss., Pinaceae Lindl.

Колекційно-експозиційна ділянка "Трояндовий струмок", що органічно оптимізована на Південно-західній частині Видубииького напівбастіону, репрезентує групу грунтопокривних троянд родини Rosaceae Juss. а також Prunus serrulata Lindl. 'Kanzan'; Morus nigra L. 'Pendula'; Robinia pseudoacacia L. 'Umbraculifera'; Fraxinus excelsior L. 'Pendula'.

На сучасній колекційно-експозиційній ділянці "Голонасінні" збереглися Північно-східна частина Видубицького напівбастіону та Горнверк. Рослини, що трапляються на маршруті: Picea pungens 'Glauca', Ginkgo biloba L., Taxus baccata 'Aurea'i, Taxus cuspidata Siebold \& 
Zucc., Picea glaca 'Conica', Pinus densiflora Siebold \& Zucc.; Pinus ponderosa Douglas ex C. Lawson, Pinus cretacea (Kalenicz.) Kondr.; Pinus nigra J. F. Arnold., Juniperus conmmunis L.; Juniperus polycarpos var. seravschanica
(Kom.) Kitam.; Juniperus $\times$ pfitzeriana (Späth) P. A. Schmidt; Juniperus pseudosabina Fisch. \& C. A. Mey; Abies concolor (Gordon) Lindl. ex Hildebr., Larix decidua Mill.

Табл. 1. Ботанічна складова локацій маршруту "Таємниці Звіринецького укріплення" /

Botanical component of the locations of the route named Mysteries of the Zvirynets Fortification

\begin{tabular}{|c|c|c|c|c|c|c|}
\hline \multirow[b]{2}{*}{$\begin{array}{l}\text { № } \\
3 / \text { ח }\end{array}$} & \multirow[b]{2}{*}{$\begin{array}{c}\text { Назва збережених } \\
\text { елементів укріплення }\end{array}$} & \multirow[b]{2}{*}{$\begin{array}{c}\text { Назва сучасної } \\
\text { колекційно-експозиційної ділянки }\end{array}$} & \multicolumn{4}{|c|}{ Кількість } \\
\hline & & & $\begin{array}{c}\text { види } \\
\text { (species) }\end{array}$ & $\begin{array}{c}\text { гібриди } \\
\text { (nothotaxa) }\end{array}$ & $\begin{array}{l}\text { форми } \\
\text { (form) }\end{array}$ & \begin{tabular}{|c|} 
сорти, \\
культи вари \\
(sort, cultivar)
\end{tabular} \\
\hline 1 & Контрміні галереї & \multirow{2}{*}{$\begin{array}{c}\text { "Сад Ароматів" } \\
\text { "Декоративні представники родини } \\
\text { Cornaceae" }\end{array}$} & \multirow{2}{*}{$\begin{array}{l}45 \\
10\end{array}$} & \multirow{2}{*}{$\overline{1}$} & \multirow{2}{*}{$\begin{array}{l}2 \\
3\end{array}$} & \multirow{2}{*}{$\begin{array}{l}33 \\
26\end{array}$} \\
\hline 2 & Гласис перед Південним люнетом & & & & & \\
\hline 3 & Равелін & "Гірський сад " & 94 & - & 11 & 40 \\
\hline 4 & $\begin{array}{c}\text { Південно-західна частина } \\
\text { Видубицького напівбастіон }\end{array}$ & "Трояндовий струмок" & 3 & - & 5 & 26 \\
\hline 5 & $\begin{array}{c}\text { Північно-східна частина } \\
\text { Видубицького напівбастіону }\end{array}$ & $\begin{array}{c}\text { Південно-західна частина сучасної } \\
\text { території "Голонасінні" }\end{array}$ & \multirow{2}{*}{66} & \multirow{2}{*}{5} & \multirow{2}{*}{62} & \multirow[b]{2}{*}{ - } \\
\hline 6 & Горнверк & $\begin{array}{c}\text { Північно-східна частина ділянки } \\
\text { "Голонасінні" } \\
\end{array}$ & & & & \\
\hline 7 & Печерський бастіон & \multirow{2}{*}{ "Березовий гай" } & \multirow{2}{*}{45} & \multirow{2}{*}{4} & \multirow{2}{*}{5} & \multirow{2}{*}{-} \\
\hline 8 & Повний бастіон & & & & & \\
\hline \multirow{4}{*}{9} & \multirow{4}{*}{ Великий бастіон } & "Культурної флори" & 936 & 42 & 436 & 356 \\
\hline & & "Квітнико-декоративних рослин" & 922 & 10 & 37 & 4192 \\
\hline & & "Топіарного мистецтва" & 17 & - & & 20 \\
\hline & & Західна частина ділянки "Сад Троянд" & 26 & - & 11 & 530 \\
\hline
\end{tabular}
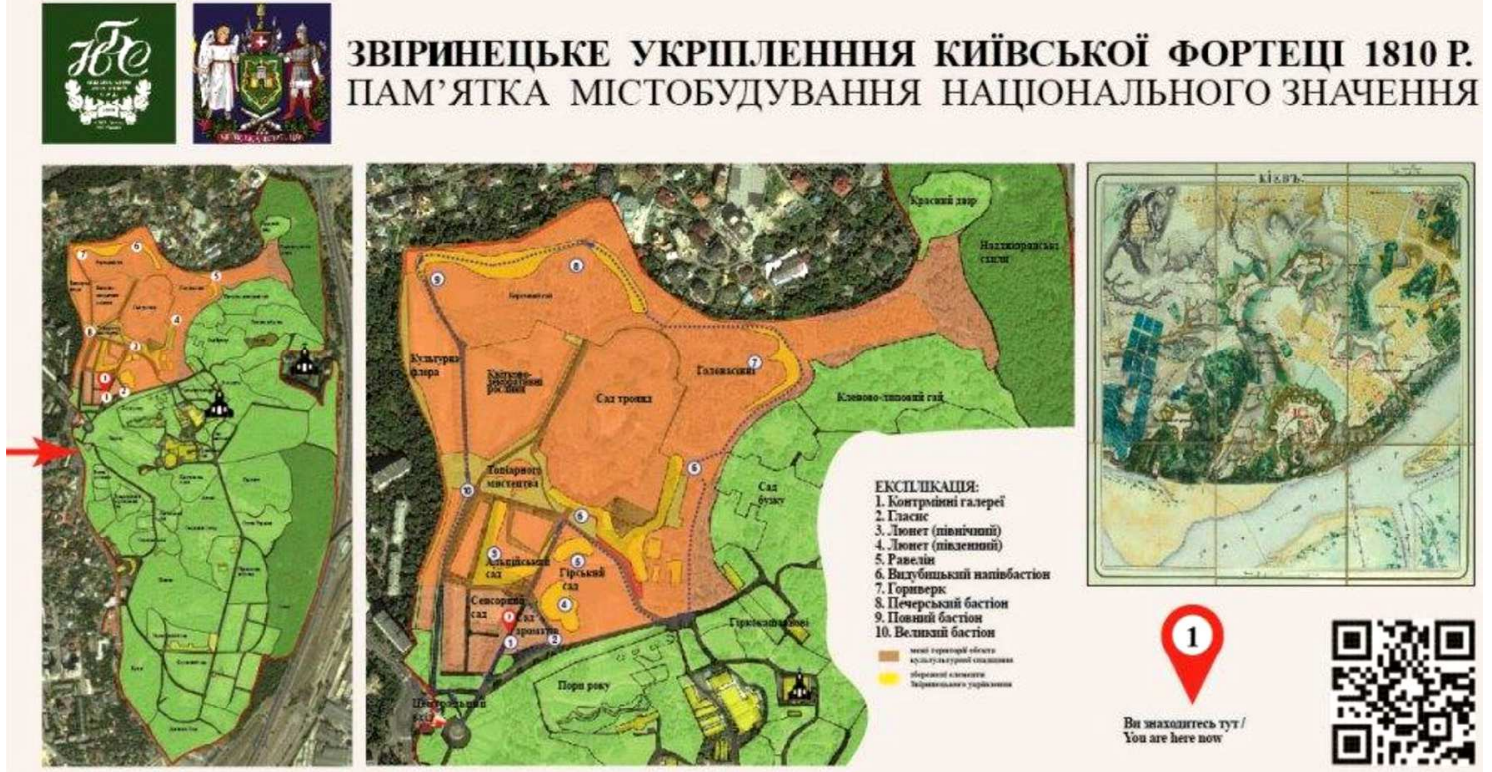

1. Контрміні галереї Звіринецького укріплення

Звіринецьке бастіонне земляне укріплення у формі неправильної пентаграми було оснащене необхідними підземними потаємними виходами за межі укріплень - мінними та контрмінними спорудами.

Контрмінні галереї призначались для виявлення ворожих підкопів під час облоги. У разі виявлення таких робіт здійснювався підрив спеціального заряду - камуфлету, який руйнував ворожий підкоп на цьому напряму.

Сьогодні про контрміні галереї нічого не нагадує, лише кропітка робота спеціалістів допомогла нам розпізнати, що одна із гравійних доріжок яка веде від альтанки ( в минулому глассіса) на дубову алею нагадує траєкторію контр мінної галереї. На території яку колись займали мінні та контрмінні споруди укріплення сьогодні розташовані експозиційні ділянки «Сад Ароматів» та «Декоративні представники родини Cогnасеае».

Рис. 1. Макет розробленого інформаційно-презентаційного стенду локації № 1 Контрміні галереї Звіринецького укріплення /

Layout of the developed information and presentation board of location $\mathrm{N} 1$ of the counter-mine galleries of Zvirinets fortification

Найбільша площа збережених фортифікаційних елементів Печерського та Повного бастіонів Звіринецького укріплення, що становлять 0,67 га, розташована на ділянці "Березовий гай". Колекційно-експозиційна ділянка "Березовий гай" представлена здебільшого видами родин Betulaceae S. F. Gray, Berberiaceae Torr et Gray та Caprifoliaceae A. L. Jussien. На маршруті репрезентовані Betula lenta L., Betula daurica, Betula schmidtii Regel, Berberis thunbergii DC., Corylus colurna L.
На жаль, елементи Великого бастіону не збереглися. На його місці розташовані сучасні колекції відділу "Культурної флори", яка нараховує понад 1861 таксон рослин (переважно з родин Amaranthaceae Juss., Asteraceae, Brassicaceae Burnett, Cyperaceae Juss., Phytolaccaceae R. Br., Polygonaceae Juss., Ranunculaceae Juss., Hypericaceae Juss., Rutaceae Juss., Lamiaceae Lindl. та ін.) та відділу "Квітниково-декоративних рослин" представлені 5180 таксонами. Також на місці Великого бастіону розташовано колекційно-експозиційну ділянку 
"Топіарного мистецтва", яка презентує стрижені форми з використанням видів і форм Ligustrum vulgare L., Thuja occidentalis L., Taxus baccata L., Buxus sempervirens L., Carpinus betulus L. та ін.

Для забезпечення дотримання вимог режиму охорони і збереження природного середовища на території розташування пам'ятки та обмеження негативних впливів антропогенного навантаження під час їі відвідуван- ня, створено умови запобігання перебуванню відвідувачів за межами наявних у ботанічному саду стежок з асфальтовим покриттям та покриттям з грунтовою відсипкою. Для цього траєкторію маршруту, що повторює контури укріплення, розроблено 3 використанням наявної дорожньо-стежкової мережі (табл. 2). За маршрутом встановлено необхідні знаки єдиного зразка для територій та об'єктів природно-заповідного фонду України [19].

Табл. 2. Дорожньо-стежкова мережа за маршрутом "Тасмниці Звіринецького укріплення" / Road network on the route named Mysteries of the Zvirynets Fortification

\begin{tabular}{|c|c|c|c|c|}
\hline $\begin{array}{c}\text { Частина маршруту } \\
\text { між локаціями }\end{array}$ & Протяжність, м & Тривалість, хв & $\begin{array}{c}\text { Покриття дорожньо-стежкової } \\
\text { мережі }\end{array}$ & $\begin{array}{c}\text { Стан дорожньо-стежкової } \\
\text { мережі }\end{array}$ \\
\hline $1-2$ & 85 & 2 & грунтове з відсипкою & Добрий \\
\hline $2-3$ & 263 & 6 & асфальт & Добрий \\
\hline $3-4$ & 242 & 5 & асфальт & Добрий \\
\hline $4-5$ & 430 & $11-12$ & асфальт & Задовільний \\
\hline $5-6$ & 353 & 8 & асфальт & Задовільний \\
\hline $6-7$ & 530 & 12 & асфальт & Добрий \\
\hline $7-8$ & 372 & 8 & асфальт & Задовільний \\
\hline $8-9$ & 440 & 10 & асфальт & Задовільний \\
\hline Всього & 2715 & 62 & - & - \\
\hline
\end{tabular}

Обговорення результатів дослідження. У процесі дослідження проаналізовано літературні джерела, обстежено збережені елементи укріплення, виявлено потенційні можливості репрезентації маловідомої історико-культурної пам'ятки національного значення "Звіринецьке укріплення київської фортеці 1810 р." на території об'єкта природно-заповідного фонду (ПЗФ) України - Національного ботанічного саду ім. М. М. Гришка НАНУ.

Розроблено еколого-історичний маршрут, що репрезентує дев'ять атрактивних збережених елементів пам'ятки Звіринецького укріплення, 10 колекційно-експозиційних ділянок ботанічного саду (представлено близько 50 таксонів рослин). Протяжність маршруту становить близько 3 км, який відвідувачі долають пішком за одну годину.

Траєкторія еколого-історичного маршруту з використанням наявної дорожньо-стежкової мережі повторює контури унікального укріплення, відповідає вимогам охорони та збереження територій об'єктів ПЗФ України. Стан покриття доріжок дає можливість використання маршруту відвідувачами 3 дітьми та людям 3 особливими потребами.

Маршрут оснащений сучасними інформаційними стендами, що дає змогу відвідувачам самостійно ознайомитися (без супроводу екскурсовода) 3 історією пам'ятки та експозиційними ділянками НБС.

\section{Висновки / Conclusions}

Вперше зібрано та адаптовано для широкого загалу наукову інформацію щодо пам'ятки культурної спадщини "Звіринецьке укріплення Київської фортеці 1810 р.", розташованої на території НБС, із застосуванням інноваційно-інформаційних технологій (ГIC та QR - кодування). Розроблено еколого-історичний маршрут "Таємниці Звіринецького укріплення", що репрезентує збережені елементи укріплення та колекційно-експозиційні ділянки території Національного ботанічного саду імені М. М. Гришка НАН України, який сприятиме збереженню культурної спадщини, охороні природи і об'єктів ПЗФ.

Розроблення заходів із репрезентації історико-культурної пам'ятки "Звіринецьке укріплення Київської фортеці 1810 р." можна використати для популяризації та репрезентації інших пам'яток історико-культурної спадщини на території НБС та подібних територіях ПЗФУ зокрема.

\section{References}

1. Althaim, L., \& Bordun, O. (2020). Vykorystannia heoloho-heomorfolohichnykh obiektiv Podilskoho Prydnisteria v ekskursiinii diialnosti. Problemy heomorfolohii i paleoheohrafii, 1(11), 230 249. https://doi.org/10.30970/gpc.2020.1.3210

2. Andriienko, T. L., Onyshchenko, V. A., Kliestov, M. L., et al. (2001). Systema katehorii pryrodno-zapovidnoho fondu Ukrainy ta pytannia yii optymizatsii. Kyiv: Fitosotsiotsentr, 60 p. [In Ukrainian].

3. Boiaryn, M. V., Voloshyn, V. U., \& Tsos, O. O. (2020). Shtuchno stvoreni obiekty pryrodno zapovidnoho fondu - parky-pamiatky sadovoparkovoho mystetstva ta yikh reprezentatyvnist u Volynskii oblasti. Liudyna ta dovkillia. Problemy neoekolohii, Vol. 34, 113-140. https://doi.org/10.26565/1992-4224-2020-34-13

4. Cherevenko, T. M., \& Trofymenko, N. M. (2011). Rol botanichnykh sadiv i dendroparkiv Ukrainy u zberezhenni bioriznomanittia. KhIII zizd Ukrainskoho botanichnoho tovarystva: materialy KhIII zizdu Ukrainskoho botanichnoho tovarystva m. Lviv, 19-23 veresnia 2011. Nats. akad. nauk Ukrainy, Lviv, 242 p. [In Ukrainian].

5. Dumacheva, E. V., Tokhar, V. K., Yaseniuk, S. N., et al. (2013). Razvytye botanycheskoho sada NYU "Belhu" kak unykalnoho obekta jekolohycheskohoturyzma. Visnyk Kharkivskoho Natsionalnoho universytetu imeni $V$. N. Karazina: seriia "Mizhnarodni vidnosyny. Ekonomika. Krainoznavstvo. Turyzm", No. 1086, 140-142. [In Ukrainian].

6. Ekolohichnyi pasport m. Kyiv. (2019). 129 p. Retrieved from: https://ecodep.kyivcity.gov.ua/files/2020/9/1/eco pasport 2019.pdf. [In Ukrainian]

7. Hrynova, M. V., \& Arkanova, A. A. (2015). Avtorskyi proekt "Rozroblennia ratsionalnoho ekoloho-ekonomichnoho marshrutu botanichnoiu pamiatkoiu pryrody "Kochubeivski duby" yak odyn z peredovykh shliakhiv pidvyshchennia ekolohichnoi kultury natsii. Aktualni problemy botaniky ta ekolohii: materialy Mizhnar. konf., m. Poltava, 15-20 ver. 2015. NAN Ukrainy, In-t bot. im. M. H. Kholodnoho Kyiv, Poltava, 153-154. [In Ukrainian].

8. Kliuenko, O. V. Klymenko, A. V., Verhun, H. M., \& Loia, V. V. (2018). Istorychni aspekty rozvytku dilianok NBS ta yikh suchasne vykorystannia. Key Issues of Education and Sciences: development Prospects for Ukraine and Poland: proceedings of theInternational Multidisciplinary Conference, Stalowa Wola, Republic of Poland, 20-21 July 2018. Stalowa Wola, Vol. 4, 75-78. [In Ukrainian]. 
9. Klymenko, A. V., \& Kliuienko, O. V. (2020). Transformatsiia landshaftiv terytorii botanichnoho sadu imeni M. M. Hryshka NAN Ukrainy v istorychnomu aspekti. Naukovi zapysky Sumskoho derzhavnoho pedahohichnoho universytetu im. A. S. Makarenka: Heohrafichni nauky, 2(1), 153-160. https://doi.org/10.5281/zenodo.376620

10. Konventsiia pro okhoronu vsesvitnoi kulturnoi i pryrodnoi spadshchyny 1972: ratyfikovano Ukazom Prezydii Verkhovnoi Rady № 6673-XI vid 04.10.88. (1988) . [In Ukrainian]. Retrieved from: https://zakon.rada.gov.ua/laws/show/995 089\#Text

11. Kovalenko, O. V. (2020). Uzahalnena metodyka rozrobky ekskursiinykh marshrutiv $\mathrm{v}$ Ukraini. Industriia turyzmu y sfera hostynnosti $v$ Ukraini ta sviti: suchasnyi stan, problemy ta perspektyvy rozvytku: materialy II mizhnarodnoi nauk.-prakt. konf., Lutsk, 195-199. [In Ukrainian].

12. Novikova-Vyhran, O. S., Vialets, A. V. (Eds.), Kuziak, O. H., Datsiuk, O. A., et al. (2018). Kyivska fortetsia (kolektyvna monohrafiia), Kyiv: Natsionalnyi istoryko-arkhitekturnyi muzei "Kyivska fortetsia", 92 p. [In Ukrainian].

13. Onyshchenko, V. A. (2000). Oblik zavdan ta rezhymiv pryrodnozapovidnykh terytorii. Zapovidna sprava v Ukraini, 6(1-2), 3-6. [In Ukrainian].

14. Pasport. [In Ukrainian]. Retrieved from: https://archive.org/details/20200827 20200827 1837/mode/2up

15. Podolkhova, M. O. (2018). Dendrolohichni parky Ukrainskoho Polissia (kompleksna otsinka, terytorialna orhanizatsiia ta landshaftno-kompozytsiinyi analiz). Abstract of Candidate Dissertation for Agricultural Sciences (06.03.01 - Forest crops and Phytomelioration). Kyiv, 24 p. [In Ukrainian].

16. Pro vnesennia obiektiv kulturnoi spadshchyny natsionalnoho znachennia do Derzhavnoho reiestru nerukhomykh pamiatok Ukrainy: postanova Kabinetu Ministriv Ukrainy vid 10.10.2012. №929. Retrieved from: http://zakon2.rada.gov.ua/laws/show/9292012-\%D0\%BF. [In Ukrainian]

17. Pro zatverdzhennia Polozhennia pro yedyni derzhavni znaky ta anshlahy na terytoriiakh ta obiektakh pryrodno-zapovidnoho fon- du Ukrainy: nakaz Ministerstva Okhorony Navkolyshnoho Pryrodnoho Seredovyshcha Ukrainy vid 29.03.1994 № 30. Retrieved from: zakon.rada.gov.ua/laws/show/z0072-94\#Text. [In Ukrainian]

18. Rubtcova, E. L., Chuvikina, N. V., \& Klimenko, A. V. (2017). Ispolzovanie pamiatnikov kultovoi arkhitektury v landshaftakh Natcionalnogo botanicheskogo sada im. N. N. Grishko NAN Ukrainy. Landshaftnaia arkhitektura $v$ botanicheskikh sadakh $i$ dendroparkakh: materialy IKh Mezhdunar. konf. g. Solovki, 4-6 sent. 2017 g. Solovki, 103-106. [In Russian].

19. Shevtsova, L. V., Shevtsova, N. L., \& Hlukhovskyi, P. V. (2018). Zastosuvannia funktsionalnoho zonuvannia pryrodookhoronnykh terytorii dlia zberezhennia bioriznomanittia. Ekolohichni nauky, 2(21), 186-191. Retrieved from: http://ekmair.ukma.edu.ua/handle/123456789/15400. [In Ukrainian]

20. Sitkareva, O. V. (1997). Kievskaia krepost XVIII - XIX vv. Kiev: Natcionalnyi Kievo-Pecherskii istoriko-kulturnyi zapovednik, 200 p. [In Russian].

21. Sobko, V. H., \& Haponenko, M. B. (1996). Introduktsiia ridkisnykh i znykaiuchykh roslyn flory. Kyiv: Nauk. dumka, 283 p. [In Ukrainian].

22. Vialets, A. (2018). Zvirynetske ukriplennia Kyivskoi fortetsi: istoriia budivnytstva. Arkheolohiia \& Fortyfikatsiia Ukrainy" materialy VIII Vseukrainskoi nauk.-prakt. konf., m. Kamianets-Podilskyi, 2018. / FOP. Buinytskyi O. A. Kamianets-Podilskyi, 257264. [In Ukrainian].

23. Zaimenko, N. V., \& Melezhyk, O. O. (2015). Pro suchasnyi stan, problemy i perspektyvy zberezhennia ta zbahachennia roslynnoho riznomanittia v botanichnykh sadakh i dendroparkakh Ukrainy. Visnyk Natsionalnoi akademii nauk Ukrainy, No. 9, 33-38. [In Ukrainian].

24. Zvirynetske ukriplennia Kyivskoi fortetsi 1810. (2012). Pasport pamiatky mistobuduvannia natsionalnoho znachennia. Min-vo Kultury Ukrainy. Nauk.-doslid. In.-t pamiatkookhoronnykh doslidzhen. Kyiv, 14 p. [In Ukrainian]. Retrieved from: https://archive.org/details/zvirynets-fort-passport-of-the-object/mode/2up

V. F. Pylypchuk, R. V. Boiko

M. M. Gryshko National Botanical Garden, NAS Ukraine, Kyiv, Ukraine

\section{MYSTERIES OF THE ZVIRYNETS FORTIFICATIONS MONUMENT ON THE TERRITORY OF THE M. M. GRYSHKO NATIONAL BOTANICAL GARDEN OF THE NATIONAL ACADEMY OF SCIENCES OF UKRAINE}

One of the modern scientific directions of M. M. Gryshko National Botanical Garden of the National Academy of Sciences of Ukraine is a theoretical background and practical implementation of measures to promote and represent monuments of historical and cultural heritage in the territories of the Nature Reserve Fund of Ukraine. In accordance with the legal requirements for the regime of protection and preservation of the natural environment, such measures have their own characteristics. There is a monument of urban planning of national importance Zvirynets Fortification of the Kyiv Fortress of 1810 in the territory of the botanical garden. The monument has significant historical and cultural value. Today it remains one of the little-known historical and fortification objects of Ukraine for a large number of people. Therefore we conducted the research, using descriptive and comparative methods in 20182021 in the territory of the Botanical Garden. The most optimal measure of historical and cultural monuments representation in nature reserves is the creation of historical and ecological excursion routes equipped with special information stands. Given that the route runs through the botanical garden, it is an important combination of historical data about the monument with information about plants and collection exhibition areas. The study identified the most attractive survive elements of the fortification, which are correlated with the present landscapes of the collection and exhibition areas. The features of the setting elements on the territory of the expositions with the attachments were analyzed. Information and the graphic component of the route are prepared. According to the regime of use of the botanical garden territory, the trajectory of the route with a length of more than 3 kilometers was developed using the existing road network, it repeats the contours of the unique fortification. This route is laid through the collection and exhibition areas such as Garden of Fragrances, Mountain Garden, Rose Stream, Gymnosperms, and Birch Grove, where more than 50 plant taxes are presented. As a result of the research, scientific data was collected and adapted for the general public for the first time. The information contains the data about the little-known historical and cultural monument Zvirynets Fortification of the Kyiv Fortress of 1810 located on the territory of M. M. Gryshko National Botanical Garden, NAS of Ukraine. The advantages of this study are the practical experience that can be used as a perspective for the promotion and representation of historical and cultural heritage in the reserves and botanical gardens, upholding the legal requirements for the regime of protection and preservation of the natural environment.

Keywords: cultural heritage; ecological and historical route; collection and exhibition areas of NBG; the territory of the reserve fund; fortification elements of the defence walls. 